\title{
Tinjauan Awal Struktur Jaringan Jalan di Kota Banda Aceh
}

\section{Initial Review of City Road Network Structure in Banda Aceh}

\author{
Cut Mutiawati ${ }^{1, a)}$ \& Hitapriya Suprayitno ${ }^{2, b)}$ \\ ${ }^{1)}$ Departemen Teknik Sipil, Universitas Syah Kuala, Banda Aceh. \\ ${ }^{2}$ Departemen Teknik Sipil, Institut Teknologi Sepuluh Nopember (ITS), Surabaya.
}

Koresponden : ${ }^{a}$ cutmutiawati@unsyiah.ac.id \& ${ }^{b}$ suprayitno.hita@gmail.com

\begin{abstract}
ABSTRAK
Transportasi merupakan salah satu unsur penting dalam menunjang pembangunan. Salah satu prasarana transportasi adalah jaringan jalan. Jaringan jalan ini memiliki peran penting untuk memperlancar distribusi orang dan barang dari satu tempat ketempat lainnya. Hal ini akan mendorong pertumbuhan ekonomi, sosial, budaya dan keamanan nasional serta pemerataan pembangunan. Banda Aceh adalah ibukota Provinsi Aceh yang menjadi pusat berbagai kegiatan seperti perdagangan, pendidikan dan jasa lainnya. Penelitian ini bertujuan untuk melakukan Evaluasi Struktur Jaringan Jalan di Kota Banda Aceh. Di Kota Banda Aceh dan Kawasan Sekitar terdapat 5 Pusat Kawasan Primer dan 9 Kawasan Sekunder penting. Jaringan Jalan di Kota Banda Aceh terdiri dari 11 ruas jalan Arteri Primer, 12 ruas jalan Kolektor Primer, 4 ruas jalan Arteri Sekunder dan 13 ruas Jalan Kolektor Sekunder. Struktur Jaringan Jalan bisa dikatakan bagus, karena semua Pusat Kegiatan Primer Utama dan semua Kawasan Sekunder Utama dihubungkan dengan baik oleh Ruas-ruas Jaringan Jalan sesuai dengan Fungsinya.
\end{abstract}

Kata Kunci : manajemen aset infrastruktur, jalan, struktur jaringan jalan, Banda Aceh

\section{PENDAHULUAN}

Template Transportasi merupakan salah satu unsur penting dalam menunjang pembangunan. Salah satu prasarana transportasi adalah jaringan jalan. Jaringan jalan ini memiliki peran untuk memperlancar distribusi orang dan barang dari satu tempat ketempat lainnya. Hal ini akan mendorong pertumbuhan ekonomi, sosial, budaya dan keamanan nasional serta pemerataan pembangunan. Banda Aceh adalah ibukota Provinsi Aceh yang menjadi pusat berbagai kegiatan seperti perdagangan, pendidikan dan jasa lainnya. Pertumbuhan lalu lintas, prasarana jalan dan pusat - pusat kegiatan baru menyebabkan peranan dan fungsi jalan di wilayah perkotaan mengalami perubahan.

Manajemen Aset Infrastruktur sangat dibutuhkan bagi infrastruktur jalan. Salah satu prinsip utama dalam melihat infrastruktur adalah bahwa infrastruktur diadakan untuk menjalankan fungsi tertentu (Suprayitno \& Soemitro 2018). Fungsi Jaringan Jalan bisa dilihat dari Aspek Struktur Jaringan Jalan. Dilihat dari sudut pandang Struktur Jaringan, Fungsi Jaringan Jalan adalah untuk menghubungkan Antar Pusat Kegiatan.

Untuk mengetahui tentang sistem jaringan jalan di Kota Banda Aceh yang menghubungkan pusat - pusat kegiatan tersebut maka perlu kajian tentang jaringan jalan, peranan dan fungsinya berdasarkan peraturan yang berlaku. Keluaran dari penelitian ini adalah peta jaringan jalan Kota Banda Aceh berdasarkan klasifikasi fungsi jaringan jalan 
mengacu pada Pedoman Penentuan Klasifikasi Fungsi Jalan di Kawasan Perkotaan No. Pd T18-2004.

Makalah ini menyampaikan hasil penelitian untuk mengevaluasi Struktur Jaringan Jalan di Kota Banda Aceh dikaitkan dengan fungsinya.

\section{METODA PENELITIAN}

\section{Lokasi Penelitian}

Lokasi penelitian terletak di Kota Banda Aceh secara geografis terletak antara 05 16' 15" - 05 36' 16" Lintang Utara dan 95 16' 15" - 95 22' 35" Bujur Timur dengan tinggi rata-rata 0,80 meter diatas permukaan laut. Kota Banda Aceh terdiri dari 9 Kecamatan dan 90 Desa. Luas wilayah administratif Kota Banda Aceh sebesar 61.359 Ha atau berkisar 61, $36 \mathrm{Km} 2$ dengan batas-batas sebagai berikut (Pemkot Banda Aceh, 2018):

Utara : Selat Malaka

Selatan : Kecamatan Darul Imarah dan Kecamatan Ingin Jaya Kabupaten Aceh Besar

Timur : Kecamatan Barona Jaya dan Kecamatan Darussalam Kabupaten Aceh Besar

Barat : Kecamatan Peukan Bada Kabupaten Aceh Besar

\section{Tahapan Penelitian}

Tahapan penelitian adalah sebagai berikut : studi literature, identifikasi Kota Banda Aceh (tata guna lahan, pusat kegiatan, dan jaringan jalan), identifikasi pusat kegiatan, identifikasi stuktur jaringan jalan, evaluasi struktur jaringan jalan.

\section{STUDI PUSTAKA}

Makalah ini ditujukan untuk melakukan analisis tentang Struktur Jaringan Jalan. Struktur Jaringan Jalan dibentuk oleh Klasifikasi Ruas Jalan Pembentuk Jaringan Jalan. Ruas dan Jaringan Jalan diklasifikasikan kedalam klasifikasi Status, Fungsi dan Klas Jalan.

Jalan menurut wewenang pembinaan dikelompokkan menjadi : jalan nasional, jalan provinsi, jalan kabupaten, jalan kota, jalan lingkungan serta jalan khusus (UU 38/04). Pengelompokan ini disampaikan pada Tabel 1 sebagai berikut.

Tabel 1. Klasifikasi Status Jalan

\begin{tabular}{|c|l|}
\hline Status & Pengelola \\
\hline Nasional & Pemerintah Pusat \\
\hline Provinsi & Pemerintah Provinsi \\
\hline Kota & Pemerintah Kota \\
\hline Kabupaten & Pemerintah Kabupaten \\
\hline Lingkungan & Kecamatan/Desa \\
\hline Khusus & Pemilik Jalan \\
\hline
\end{tabular}

Sumber : UU 38/04

Sistem jaringan jalan dengan peranan pelayanan jasa distribusi untuk pengembangan semua wilayah di tingkat nasional dengan semua simpul jasa distribusi yang kemudian berwujud kota, membentuk sistem jaringan jalan primer. Sedangkan, Sistem jaringan jalan dengan peranan pelayanan jasa distribusi untuk masyarakat di dalam kota membentuk sistem jaringan jalan sekunder (UU 22/09). Pengelompokkan Jaringan Jalan kedalam Jaringan Primer dan Jaringan Sekunder disampaikan pada Tabel 2 berikut ini. 
Tabel 2. Klasifikasi Jaringan dan Fungsi

\begin{tabular}{|c|l|c|}
\hline Sistem & Fungsi & Keterangan \\
\hline \multirow{4}{*}{ Primer } & Arteri & \multirow{2}{*}{ Jalan penghubung antar Pusat } \\
\cline { 2 - 2 } & Kolektor & Kegiatan Primer \\
\cline { 2 - 2 } & Lokal & \\
\hline \multirow{3}{*}{ Sekunder } & Arteri & \\
\cline { 2 - 2 } & Kolektor & Jalan diwilayah perkotaan \\
\cline { 2 - 2 } & Lokal & \\
\hline
\end{tabular}

Sumber : UU 38/04

Berdasarkan klasifikasi fungsinya, jalan dikelompokkan kedalam jalan arteri, jalan kolektor, jalan lokal, dan jalan lingkungan.

1. Jalan Arteri, yaitu jalan yang melayani angkutan umum dengan ciri-ciri perjalanan jarak jauh, kecepatan rata-rata tinggi dan jumlah jalan masuk dibatasi secara efisien.

2. Jalan Kolektor, yaitu jalan yang melayani angkutan pengumpulan dan pembagian dengan ciri-ciri merupakan perjalanan jarak sedang, kecepatan rata-rata sedang dan jumlah jalan masuk dibatasi.

3. Jalan lokal, yaitu jalan yang melayani angkutan setempat dengan ciri-ciri perjalanan jarak dekat, kecepatan rata-rata rendah dengan jumlah jalan masuk tidak dibatasi.

4. Jalan lingkungan, yaitu jalan umum yang berfungsi melayani angkutan lingkungan dengan ciri perjalanan jarak dekat, dengan kecepatan rata-rata rendah.

Ruas Jalan dalam Sistem Jaringan Primer berfungsi untuk menghubungkan antar Pusat Kegiatan, baik Pusat Kegiatan Nasional (PKN), Pusat Kegiatan Wilayah (PKW), Pusat Kegiatan Lokal (PKL) dan Persil. Matriks Klas Fungsi Jalan dengan perannya untuk menghubungkan berbagai klas Pusat Kegiatan dapat dilihat pada Tabel 3 sebagai berikut.

Tabel 3. Hubungan Pusat Kegiatan dengan Sistem Jaringan Primer

\begin{tabular}{|l|c|c|c|c|c|}
\hline & PKN & PKW & PKL & PK,PKL & Persil \\
\hline PKN & Arteri & Arteri & Kolektor & Lokal & Lokal \\
\hline PKW & Arteri & Kolektor & Kolektor & Lokal & Lokal \\
\hline PKL & Kolektor & Kolektor & Lokal & Lokal & Lokal \\
\hline PK $<$ PKL & Lokal & Lokal & Lokal & Lokal & Lokal \\
\hline Persil & Lokal & Lokal & Lokal & Lokal & Lokal \\
\hline
\end{tabular}

Sumber: Pedoman Konstruksi dan Bangunan Pd T-18-2004

Sedangkan Matriks Hubungan antara Klas Kawasan Perkotaan dengan Peranan Ruas Jalan yang menghubungkan dalam Sistem Jaringan Sekunder disampaikan pada Tabel 4.

Tabel 4. Hubungan antara Pusat Kegiatan Perkotaan dengan Jaringan Jalan Sekunder

\begin{tabular}{|l|c|c|c|c|c|}
\hline \multicolumn{1}{|c|}{ Kawasan } & Primer & Sekunder I & Sekunder II & $\begin{array}{c}\text { Sekunder } \\
\text { III }\end{array}$ & Perumahan \\
\hline Primer & - & Arteri & - & - & - \\
\hline Sekunder I & Arteri & Arteri & Arteri & - & Lokal \\
\hline Sekunder II & - & Arteri & Kolektor & Kolektor & Lokal \\
\hline Sekunder III & - & - & Kolektor & - & Lokal \\
\hline Perumahan & - & Lokal & Lokal & Lokal & - \\
\hline
\end{tabular}

Sumber : Pedoman Konstruksi dan Bangunan Pd T-18-2004 
Ruas Jalan juga diklasifikasikan berdasarkan Ukuran Kendaraan Maksimum yang bisa melewati Ruas Jalan tersebut. Ukuran Kendaraan Maksimum diukur dalam dimensi Lebar Maksimum, Panjang Maksimum, Beban Sumbu Terberat. Klasifikasi ini disebut sebagai Klas Jalan (UU 38/04; PP 34/06). Klasifikasi Klas Jalan disampaikan pada pada Tabel 5 sebagai berikut.

Tabel 5. Klasifikasi Jalan Berdasarkan Kelas Jalan

\begin{tabular}{|c|c|c|c|}
\hline \multirow{2}{*}{$\begin{array}{c}\text { Kelas } \\
\text { Jalan }\end{array}$} & \multicolumn{3}{|c|}{ Ukuran Kendaraan } \\
\cline { 2 - 4 } & Lebar (mm) & $\begin{array}{c}\text { Panjang } \\
(\mathbf{m m})\end{array}$ & Sumbu Terberat \\
\hline I & $<2.500$ & $<18.000$ & $>10$ \\
\hline II & $<2.500$ & $<12.000$ & $<10$ \\
\hline III & $<2.500$ & $<8.000$ & $<8$ \\
\hline
\end{tabular}

Sumber : UU 38/04, PP 34/06.

\section{ANALISIS STRUKTUR JARINGAN JALAN}

\section{Tinjauan Struktur Jaringan Jalan}

Kajian ini bertujuan untuk melihat apakah Struktur Jaringan Jalan di Kota Banda Aceh cukup bagus atau tidak. Struktur Jaringan Jalan dikatakan bagus kalau Seluruh Pusat Kegiatan Primer dan Seluruh Wilayah Sekunder di Kota Banda Aceh telah dihubungkan oleh Ruas Jalan sesuai dengan Ketentuan yang ada. Misal apakah Pusat Kegiatan Nasional di Kota Banda Aceh sudah dihubungkan oleh Ruas Jalan Arteri Primer, apakah Kawasan Primer di Kota Banda Aceh sudah dihubungkan dengan Kawasan Sekunder I oleh Ruas Jalan Arteri Sekunder, dan hubungan-hubungan yang lain.

\section{Identifikasi Pusat Kegiatan Primer dan Kawasan Sekunder di Kota Banda Aceh dan Sekitar}

Untuk kajian ini diperlukan Identifikasi Pusat Kegiatan Primer dan Identifikasi Kawasan Sekunder di Kota Banda Aceh dan sekitarnya.

\section{Identifikasi Pusat Kegiatan Primer di Kawasan Sekitar Kota Banda Aceh}

Kota Banda Aceh adalah ibu kota Provinsi Aceh, yang terletak diujung utara Pulau Sumatera. Beberapa Pusat Kegiatan Primer penting di Kawasan Sekitar Kota Banda Aceh adalah : Bandara Sultan Iskandar Muda, Pelabuhan Laut Malahayati. Selain itu, Tiga Jalan Nasional penting perlu untuk disebut, yaitu : Jalan Trans Sumatra, Jalan Nasional disepanjang Pantai Timur Sumatera, dan Jalan Nasional disepanjang Pantai Barat Sumatra. Identifikasi ini disampaikan dalam bentuk peta pada Gambar 1 sebagai berikut. 


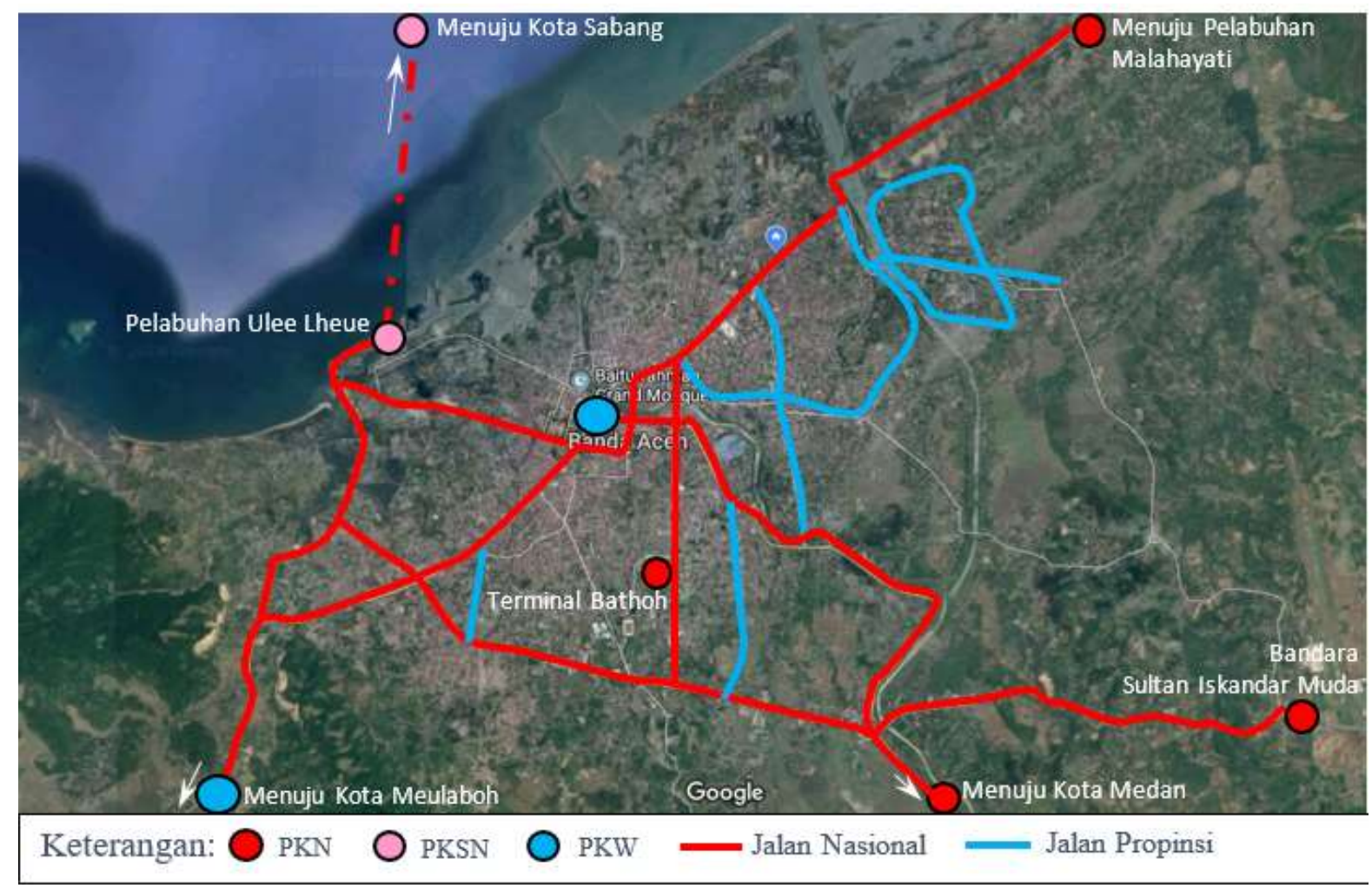

Gambar 1. Peta Pusat Kegiatan Primer, Jalan Nasional dan Jalan Propinsi Kota Banda Aceh

\section{Identifikasi Pusat Kegiatan Primer di Kota Banda Aceh}

Saat ini Kota Banda Aceh memiliki 2 pusat kegiatan utama yaitu pusat kegiatan kota lama dan pusat kegiatan kota baru. Kedua pusat kegiatan ini merupakan pusat kegiatan primer dengan skala pelayanan kota dan regional. Pusat kegiatan kota lama terletak di kawasan Pasar Aceh dan Peunayong. Pasar Aceh terletak di Kecamatan Baiturrahman. Sedangkan Pasar Peunayong terletak di Kecamatan Kuta Alam. Pusat kegiatan kota baru terletak di Pasar Bathoh yang terletak di Kecamatan Lueng Bata. Fungsi kedua pusat kegiatan utama ini merupakan pusat perdagangan, jasa, perkantoran dan pemerintahan. Pusat kegiatan utama ini didukung oleh 2 Sub Pusat Kota (SPK) yaitu SPK Kutapang dan SPK Ulee Kareng. SPK Kutapang melayani Kecamatan Jaya Baru dan Kecamatan Meuraxa, sedangkan SPK Ulee Kareng melayani Kecamatan Syiah Kuala dan Kecamatan Ule Kareng. Kedua sub pusat kota ini berfungsi sebagai pusat perdagangan, jasa dan pemukiman dengan skala pelayanan kota dan regional.

Selain itu, di Kota Banda Aceh terdapat Pusat Kegiatan Nasional, yaitu : Terminal Bis Bathoh - Terminal Tipe A, Masjid Raya Baiturrahman, Universitas Syiah Kuala dan Kantor Gubernur. Di Kota Banda Aceh juga terdapat Pusat Kegiatan Wilayah Pelabuhan Penyeberangan Ulee Lheue. Pelabuhan Penyeberangan ini melayani Penyeberangan ke Pulau Weh.

\section{$\underline{\text { Identifikasi Kawasan Sekunder di Kota Banda Aceh }}$}

Selain itu Kota Banda Aceh saat ini juga berkembang pusat kegiatan lingkungan yang merupakan kawasan sekunder 1, 2 dan 3 yaitu:

1. Pusat kegiatan di Lampulo Kecamatan Kuta Alam (Kawasan sekunder 2/F22). Kawasan ini berfungsi sebagai pelabuhan ikan dan pengolahannya serta pemukiman, dengan skala pelayanan, lokal, kota dan regional. 
2. Pusat kegiatan di Jambo Tape Kecamatan Kuta Alam (Kawasan sekunder 2/F22). Kawasan ini berfungsi sebagai pusat pemerintahan, perkantoran dan perdagangan dan jasa, dengan skala pelayanan, lokal, kota dan regional.

3. Pusat kegiatan di Darussalam Kecamatan Syiah Kuala (Kawasan sekunder 2/F22). Kawasan ini berfungsi sebagai pendidikan, perdagangan dan jasa serta pemukiman, dengan skala pelayanan lokal, kota dan regional.

4. Pusat kegiatan di Blang Oi dan Ulele Kecamatan Meuraxa (Kawasan sekunder 2/F22). Kawasan ini berfungsi sebagai pusat pelabuhan antar pulau, perikanan, wisata, perdagangan dan jasa serta pemukiman. Skala pelayanan lokal, kota dan regional.

5. Pusat kegiatan di Lamtemen Kecamatan Jaya Baru (Kawasan sekunder 2/F22). Kawasan ini berfungsi sebagai pertkantoran, perdagangan dan jasa serta pemukiman. Skala pelayanan lokal, kota dan regional.

6. Pusat kegiatan di Jeulingke Kecamatan Syiah Kuala (Kecamatan Kawasan sekunder 3/F23). Kawasan ini berfungsi sebagai pusat pemerintahan propinsi, perkantoran, perdagangan dan jasa serta pemukiman. Skala pelayanan lokal, kota dan regional

7. Pusat kegiatan di Neusu Kecamatan Baiturrahman Kawasan sekunder 3/F23). Kawasan ini berfungsi sebagai perdagangan dan jasa serta pemukiman. Skala pelayanan lokal dan kota.

8. Pusat kegiatan di Lueng Bata Kecamatan Lueng Bata (Kecamatan Kawasan sekunder 3/F23). Kawasan ini berfungsi perdagangan dan jasa serta pemukiman. Skala pelayanan lokal dan kota.

9. Pusat kegiatan di Mibo Kecamatan Banda Raya (Kecamatan Kawasan sekunder 3//F23). Kawasan ini berfungsi sebagai pusat pemerintahan kota, perkantoran serta pemukiman. Skala pelayanan lokal dan kota.

\section{Identifikasi Jaringan Jalan di Wilayah Kota Banda Aceh}

Jalan Berdasarkan kewenangan pembinaannya dikelompokkan menjadi Jalan Nasional, Jalan Propinsi, dan Jalan Kabupaten/Kota dan Jalan Desa serta Jalan Khusus. (UU 38/04). Jaringan Jalan di Kota Banda Aceh terdiri dari Jalan Nasional yang pembinaannya dilakukan oleh Pemerintah Pusat (Kementerian PUPR), Jalan Propinsi dengan pembinaan dilakukan oleh Pemerintah Propinsi Aceh (Dinas PUPR Propinsi Aceh), dan Jalan Kota yang pembinaannya dilakukan oleh Pemerintah Kota (Dinas PUPR Kota Banda Aceh) serta jalan desa/kelurahan yang pembinaannya dilakukan oleh pemerintah desa. Peta Pusat kegiatan sekunder dan jaringan jalan Kota Banda Aceh berdasarkan kewenangan pengawasan dan pembinaan jalan dapat dilihat pada Gambar 2 sebagai berikut. 


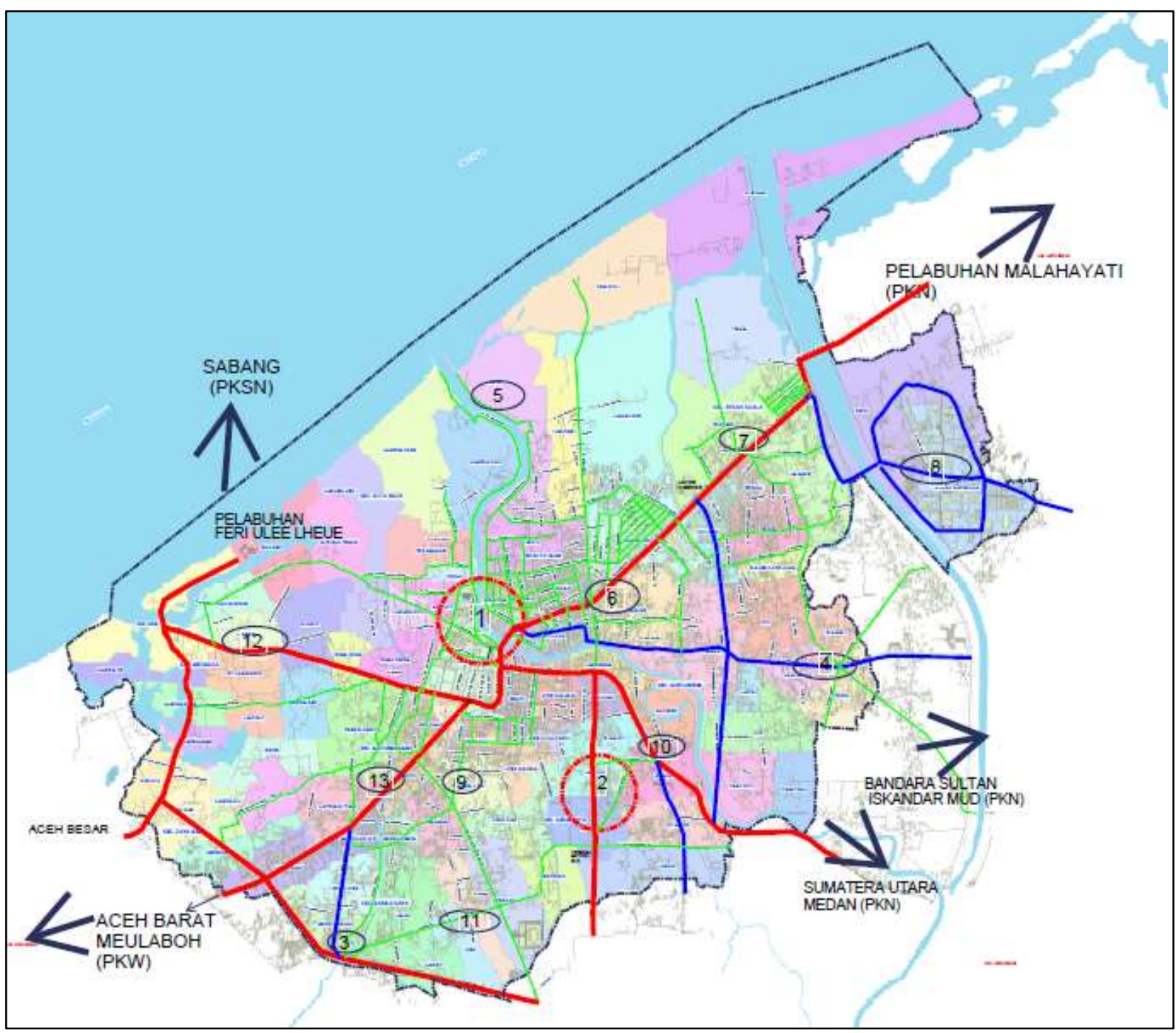

Gambar 2. Peta Jaringan Jalan Kota Banda Aceh berdasarkan Status

Identifikasi Jalan Nasional

Berdasarkan Keputusan Menteri Pekerjaan Umum Nomor: SK Menteri PU No.248/KPTS/M/2015 yang termasuk Jalan Nasional di Kota Banda Aceh dapat dilihat pada Tabel 6 sebagai berikut. 
Tabel 6. Jalan Nasional di Kota Banda Aceh

\begin{tabular}{|c|l|c|c|c|}
\hline No & \multicolumn{1}{|c|}{ Nama Jalan } & $\begin{array}{c}\text { Panjang } \\
(\mathbf{K M})\end{array}$ & $\begin{array}{c}\text { Klas } \\
\text { Jalan** }\end{array}$ & Fungsi Jalan* $^{*}$ \\
\hline 1 & Jalan Laksamana Malahayati & 0,82 & II-A & Arteri Primer \\
\hline 2 & Jalan T. Nyak Arief & 2,19 & II-A & Arteri Primer \\
\hline 3 & Jalan Tgk. Daud Beureueh & 2,77 & III-A & Arteri Primer \\
\hline 4 & Jalan Tgk. Chik Ditiro & 1,11 & I-A & Arteri Primer \\
\hline 5 & Jalan Tgk. Imum Lueng Bata & 2,57 & I-A & Arteri Primer \\
\hline 6 & Jalan Mr. Mohd. Hasan & 4,04 & - & Arteri Primer \\
\hline 7 & Jalan Elak 1 ( Soekarno-Hatta) & 1,44 & - & Arteri Primer \\
\hline 8 & Jalan Elak 2 ( Soekarno-Hatta) & 6,20 & - & Arteri Primer \\
\hline 9 & Jalan Sultan Iskandar Muda & 3,73 & - & Arteri Primer \\
\hline 10 & Jalan Prof. Ibrahim Hasan & 2,00 & - & Arteri Primer \\
\hline 11 & Jalan Residen Ibnu Sya'dan/Jalan & 1,47 & - & Arteri Primer \\
\hline 12 & Pelabuhan Ulee Lheue & 1,18 & III-K1 & Kolektor Primer \\
\hline 13 & Jalan Teuku Umar & 2,05 & III-K1 & Kolektor Primer \\
\hline 14 & Jalan Sultan Alaidin Mahmudsyah & 0,99 & III-K1 & Kolektor Primer \\
\hline
\end{tabular}

Sumber : *SK Menteri PU No.248/KPTS/M/2015

** SK Menteri PU No.58/KPTS/M/2012

\section{$\underline{\text { Identifikasi Jalan Propinsi }}$}

Jalan Propinsi di Kota Banda Aceh ditetapkan berdasarkan SK Gubernur Nomor 620/1243/2015 tentang Status Ruas-Ruas Jalan sebagai Jalan Propinsi. Daftar jalan tersebut dapat dilihat pada Tabel 7 sebagai berikut.

Tabel 7. Jalan Propinsi di Kota Banda Aceh

\begin{tabular}{|c|l|c|c|}
\hline No & \multicolumn{1}{|c|}{ Nama Jalan } & $\begin{array}{c}\text { Panjang } \\
(\mathbf{K M})\end{array}$ & Fungsi Jalan \\
\hline 1 & $\begin{array}{l}\text { Jalan. Simpang Tugu Darussalam-Batas } \\
\text { Kabupaten Aceh besar }\end{array}$ & 3,61 & Kolektor Primer \\
\hline 2 & Jalan. Lingkar Darussalam & 5,37 & Kolektor Primer \\
\hline 3 & Jalan. Ir. M. Taher & 1,50 & Kolektor Primer \\
\hline 4 & Jalan. Sudirman & 1,56 & Kolektor Primer \\
\hline 5 & Jalan Ali Hasyimi & 2,20 & Kolektor Primer \\
\hline 6 & Jalan. P. Nyak Makam & 1,88 & Kolektor Primer \\
\hline 7 & Jalan. T. Iskandar & 3,32 & Kolektor Primer \\
\hline 8 & Jalan. Mayjen T. Hamzah Bendahara & 1,16 & Kolektor Primer \\
\hline 9 & $\begin{array}{l}\text { Jalan. Simpang Tujuh-Simpang Limpok (Jalan } \\
\text { Lamgapang) }\end{array}$ & 2,01 & Kolektor Primer \\
\hline
\end{tabular}

Sumber : SK Gubernur Nomor 620/1243/2015

\section{$\underline{\text { Identifikasi Jalan Kota }}$}

Jalan Kota di Banda Aceh ditetapkan berdasarkan Keputusan Walikota Banda Aceh Nomor : 221A Tahun 2010 tentang Penetapan Status Ruas-Ruas Jalan Sebagai Jalan Kota. Berdasarkan peraturan tersebut Banda Aceh memiliki 779 jalan dengan status jalan kota dan 546 dengan status jalan desa/kelurahan. Beberapa jalan kota yang terletak pada beberapa Pusat Kegiatan dapat dilihat pada Tabel 8 sebagai berikut. 
Tabel 8. Jalan Kota di Kota Banda Aceh

\begin{tabular}{|l|l|c|l|}
\hline No & \multicolumn{1}{|c|}{ Nama Jalan } & $\begin{array}{c}\text { Panjang } \\
(\text { KM })\end{array}$ & \multicolumn{1}{|c|}{ Fungsi* } \\
\hline 1 & Jalan. Malikus Saleh & 2,31 & Arteri Sekunder \\
\hline 2 & Jalan. T. Hasan Dek & 3,61 & Arteri Sekunder \\
\hline 3 & Jalan. Syiah Kuala & 5,37 & Arteri Sekunder \\
\hline 4 & Jalan. T. Panglima Polem & 1,00 & Arteri Sekunder \\
\hline 5 & Jalan. Sri Ratu Safiatuddin & 0,30 & Arteri Sekunder \\
\hline 6 & Jalan. Rama Setia Lampaseh & 2,88 & Kolektor Sekunder \\
& Kota & & \\
\hline 7 & Jalan Hasan Saleh & 0,73 & Kolektor Sekunder \\
\hline 8 & Jalan Muhammad Jam & 0,72 & Kolektor Sekunder \\
\hline 9 & Jalan. K.H. Ahmad Dahlan & 0,43 & Kolektor Sekunder \\
\hline 10 & Jalan. Tentara Pelajar & 0,48 & Kolektor Sekunder \\
\hline 11 & Jalan Diponegoro & 0,65 & Kolektor Sekunder \\
\hline 12 & Jalan. Cut Mutia & 0,64 & Kolektor Sekunder \\
\hline 13 & Jalan Khairil Anwar & 0,30 & Kolektor Sekunder \\
\hline 14 & Jalan. Jend. A. Yani & 0,74 & Kolektor Sekunder \\
\hline 15 & Jalan. Supratman & 0,38 & Kolektor Sekunder \\
\hline 16 & Jalan. Sisingamangaraja & 0,32 & Kolektor Sekunder \\
\hline 17 & Jalan. Pocut Baren & 1,00 & Kolektor Sekunder \\
\hline 18 & Jalan. T. Daud Syah & 0,54 & Kolektor Sekunder \\
\hline Sumber : Dinas Pekerjaan Umum dan Perumahan Rakyat Kota Banda Aceh, 2010 \\
\hline
\end{tabular}

$\underline{\text { Identifikasi Klas Jalan }}$

Klas jalan nasional Kota Banda Aceh berdasarkan SK Menteri PU No.58/KPTS/M/2012, Jalan Tgk Imum Lueng Bata dan Jalan Tgk Chik Ditiro merupakan jalan Kelas I yang merupakan jalan akses utama menuju Propinsi Sumatera Utara. Sedangkan Jalan Laksamana Malahayati dan Jalan T. Nyak Arief yang merupakan jalan akses dari Pelabuhan Malahayati termasuk jalan kelas II. Jalan Tgk. Daud Beureueh termasuk jalan kelas III. Jalan ini adalah terusan jalan T. Nyak Arief. Menurut Dinas Pekerjaan Umum Tahun 2016, Kota Banda Aceh tidak terdapat jalan kelas I, sedangkan SK Menteri PU No.58/KPTS/M/2012 terdapat 3,68 KM jalan kelas I. Panjang jalan menurut status dan kelas jalan di Kota Banda Aceh dapat dilihat pada Tabel 9.

Tabel 9. Panjang Jalan Menurut Status dan Klas Jalan di Kota Banda Aceh

\begin{tabular}{|c|c|c|c|c|}
\hline \multirow{2}{*}{ No } & \multirow{2}{*}{ Kelas Jalan } & \multicolumn{3}{|c|}{ Panjang Jalan (KM) } \\
\cline { 3 - 5 } & & Jalan Nasional & Jalan Provinsi & Jalan Kota \\
\hline 1 & Kelas I & 0 & 0 & 0 \\
\hline 2 & Kelas II & 18.083 & 0 & 0 \\
\hline 3 & Kelas III & 0 & 40.240 & 0 \\
\hline 4 & Kelas III-A & 0 & 0 & 166.870 \\
\hline 5 & Kelas III-B & 0 & 0 & 154.410 \\
\hline 6 & Kelas III-C & 0 & 0 & 279.680 \\
\hline 7 & Tidak Dirinci & 0 & 0 & 106.383 \\
\hline
\end{tabular}

Sumber : Dinas Pekerjaan Umum dan Perumahan Rakyat Kota Banda Aceh, 2010 


\section{Evaluasi Struktur Jaringan Jalan Berdasarkan Fungsi dan Kelas}

\section{Evaluasi Struktur Jaringan Arteri Primer}

Undang-undang Nomor 38 Tahun 2004 dan Peraturan Pemerintah No. 34 Tahun 2006 ditetapkan fungsi dan peranan jalan di perkotaan terdiri dari: jalan arteri, jalan kolektor dan lokal baik primer maupun sekunder. Jalan arteri primer menghubungkan antara Pusat Kegiatan Nasional (PKN) atau PKN dengan Pusat Kegiatan Wilayah (PKW). Jalan arteri primer Kota Banda Aceh dapat dilihat pada Tabel 10.

Jalan Laksamana Malahayati - T. Nyak Arief - Tgk. Daud Beureueh menghubungkan Kota Banda Aceh (PKW) dengan Pelabuhan Malahayati (PKN) di Krueng Raya Kabupaten Aceh Besar yang merupakan jalan akses menuju Propinsi Sumatera Utara (PKN). Jalan Tgk. Imum Lueng Bata - Jalan Chik Ditiro Menghubungkan Propinsi Sumatera Utara (PKN) dengan pusat Kota Banda Aceh (PKW). Selain itu jalan ini juga menghubungkan Kota Banda Aceh dengan Bandara Sultan Iskandar Muda (PKN). Jalan Mr. Mohd. Hasan merupakan kawasan kota baru yang menghubungkan Propinsi Sumatera Utara/Bandara (PKN) dengan Kota Banda Aceh (PKW). Jalan ini merupakan terusan Jalan Soekarno-Hatta Kabupaten Aceh Besar dan merupakan jalur bus (AKAP) dari Sumatera Utara menuju Terminal Bathoh (PKN). Terminal ini melayani angkutan AKAP dan AKDP. Jalan Elak 1 dan 2 (Jalan Soekarno-Hatta) merupakan terusan Jalan Soekarno-Hatta Di Kabupaten Aceh Besar. Sedangkan jalan akses dari Pelabuhan Feri Ulee Lheue menuju pusat kota adalah Jalan Residen Ibnu Sya'dan-Jalan Sultan Iskandar Muda menghubungkan PKSN (Sabang) dengan PKW pusat Kota Banda Aceh. Jalan Prof. Majid Ibrahim Hasan juga jalan akses dari Pelabuhan Ulee Lheue yang menghubungkan Meulaboh (Aceh Barat/PKW) dengan PKSN (Sabang).

Tabel 10. Struktur Hubungan Ruas Jalan Arteri Primer

\begin{tabular}{|c|l|c|c|}
\hline No & \multicolumn{1}{|c|}{ Nama Jalan } & \multicolumn{2}{c|}{ Hubungan } \\
\hline 1 & Jalan Laksana Malahayati/ Jalan Krueng Raya & PKN & PKW \\
\hline 2 & Jalan T. Nyak Arief & PKN & PKW \\
\hline 3 & Jalan Tgk. Daud Bereueh & PKN & PKW \\
\hline 4 & Jalan Tgk. Imum Leung Bata & PKN & PKW \\
\hline 5 & Jalan Tgk. Chik Ditiro & PKN & PKW \\
\hline 6 & Jalan Mr. Mohd. Hasan & PKN & PKW \\
\hline 7 & Jalan Elak 1 & PKN & PKSN \\
\hline 8 & Jalan Elak 2 & PKN & PKSN \\
\hline 9 & Jalan Sultan Iskandar Muda Ulee Lheue & PKSN & PKW \\
\hline 10 & Jalan Residen Ibnu Sya'dan Ulee Lheue & PKSN & PKW \\
\hline 11 & Jalan Prof. Majid Ibrahim Hasan & PKSN & PKW \\
\hline
\end{tabular}

Evaluasi Struktur Jaringan Kolektor Primer

Jalan kolektor primer menghubungkan Pusat Kegiatan Nasional (PKN) dengan Pusat Kegiatan Lokal (PKL), antar PKW, atau PKW dengan PKL. Jalan kolektor primer Kota Banda Aceh dapat dilihat pada Tabel 11 sebagai berikut. 
Tabel 11. Struktur Hubungan Ruas Jalan Kolektor Primer

\begin{tabular}{|c|l|c|c|}
\hline No & \multicolumn{1}{|c|}{ Nama Jalan } & \multicolumn{2}{c|}{ Hubungan } \\
\hline 1 & Jalan. Simpang Tugu Darussalam-Batas Kabupaten Aceh Besar & PKL & PKW \\
\hline 2 & Jalan Lingkar Darussalam & PKL & PKW \\
\hline 3 & Jalan. Ir. M. Taher & PKL & PKW \\
\hline 4 & Jalan. Sudirman & PKL & PKW \\
\hline 5 & Jalan. Ali Hasyimi & PKL & PKW \\
\hline 6 & Jalan. P. Nyak Makam & PKL & PKW \\
\hline 7 & Jalan. T. Iskandar & PKL & PKW \\
\hline 8 & Jalan. Mayjen T. Hamzah Bendahara & PKL & PKW \\
\hline 9 & Jalan. Simpang Tujuh-Simpang Limpok (Jalan. Lamgapang) & PKL & PKW \\
\hline 10 & Jalan. Cut Nyak Dien & PKW & PKW \\
\hline 11 & Jalan. Teuku Umar & PKW & PKW \\
\hline 12 & Jalan. Sultan Alaidin Mahmudsyah & PKW & PKW \\
\hline
\end{tabular}

Jalan Simpang Tugu Darussalam dan Jalan Lingkar terdapat pada kawasan pusat pendidikan dengan 2 perguruan tinggi negeri yaitu Universitas Syiah Kuala dan Universitas Islam Negeri Ar Raniry. Saat ini kawasan ini juga berkembang menjadi wilayah komersial dengan aktivitas perdagangan barang/jasa yang tinggi. Selain itu kawasan ini juga berfungsi wilayah pemukiman terutama perumahan dosen dan asrama mahasiswa. Jalan ini menjadi akses jalan bagi masyarakat Kabupaten Aceh Besar bagian timur menuju pusat Kota Banda Aceh. Jalan lingkar kampus juga merupakan akses masyarakat Kabupaten Aceh Besar menuju pusat pedidikan di kawasan Darussalam dan seterusnya menuju pusat Kota Banda Aceh.

Jalan alternatif lain bagi masyarakat Kabupaten Aceh Besar menuju kawasan Banda Aceh adalah Jalan Ir. M. Taher, Jalan Sudirman, Jalan T. Iskandar, Jalan Simpang TujuhSimpang Limpok (Jalan Lamgapang) dan Jalan Ali Hasyimi. Jalan Ir. M. Taher terhubung dengan Jalan Tgk. Imum Lueng Bata (Jalan Nasional) yang berfungsi sebagai jalan arteri primer. Jalan Ali Hasyimi menghubungkan Jalan Medan-Banda Aceh yang merupakan Jalan Nasional di Kabupaten Aceh Besar dengan Jalan T. Iskandar. Jalan Lamgapang - Jalan T. Iskandar - Jalan Mayjen Hamzah Bendahara merupakan salah satu akses jalan dari Kabupaten Aceh Besar menuju pusat Kota Banda Aceh. Jalan Panglima Nyak Makam merupakan terusan Jalan Ali Hasyimi dan berakhir pada Jalan Tgk Daud Bereueh (Arteri Primer). Demikian juga dengan Jalan Sudirman merupakan akses jalan dari Jalan Elak (Jalan Soekarno-Hatta) Banda Aceh menuju pusat Kota Banda Aceh. Jalan Cut Nyak Dhien - Jalan Teuku Umar - Jalan Sultan Alaidin Mahmudsyah merupakan jalan dari Kabupaten Aceh Barat/Meulaboh (PKW) menuju Pusat Kota Banda Aceh (PKW).

\section{Evaluasi Struktur Jaringan Arteri Sekunder}

Jalan Arteri Sekunder adalah jalan yang menghubungkan kawasan primer dengan kawasan sekunder kesatu atau menghubungkan kawasan sekunder kesatu dengan kawasan sekunder kesatu atau menghubungkan kawasan sekunder kesatu dengan kawasan sekunder kedua. Daftar jalan arteri sekunder Kota Banda Aceh dapat dilihat pada Tabel 12 sebagai berikut. 
Tabel 12. Struktur Hubungan Ruas Jalan Arteri Sekunder

\begin{tabular}{|c|l|l|l|}
\hline No & Nama Jalan & Hubungan \\
\hline 1 & Jalan. T. Hasan Dek & F1 (Bathoh) & $\begin{array}{l}\text { F22 (Jambo } \\
\text { Tape) }\end{array}$ \\
\hline 2 & Jalan Syiah Kuala & Terusan Jalan T. Hasan Dek \\
\hline 3 & Jalan. T. Panglima Polem & F21 (Ulee Kareng) & F1 (Penayong) \\
\hline 4 & Jalan. Sri Ratu Safiatuddin & F21 (Ulee Kareng) F1 (Penayong) \\
\hline 5 & Jalan Malikus Saleh & $\begin{array}{l}\text { Menghubungkan jalan arteri primer } \\
\text { (Jalan Soekarno Hatta) dengan } \\
\text { kawasan sekunder }\end{array}$ \\
\hline
\end{tabular}

Jalan T. Hasan Dek merupakan salah satu lengan Simpang Empat Surabaya (fly over) (Jalan Tgk. Imum Lueng Bata- Jalan Chik Ditiro-Jalan Mr. Mohd Hasan- Jalan T. Hasan Dek). Jalan Hasan Dek berakhir pada Simpang Empat Jambo Tape. Terusan Jalan ini adalah Jalan Syiah Kuala yang merupakan salah satu jalan menuju kawasan perikanan Lampulo. Jalan T. Panglima Polem dan Jalan Sri Ratu Safiatuddin merupakan jalan akses menuju kawasan primer Peunayong dari Jalan Tgk. Daud Beureueh dan Jalan Mayjen Hamzah Bendahara. Jalan Panglima Polem, Jalan Sri Ratu Safiatuddin, Jalan Tgk. Daud Beureueh dan Jalan Mayjen Hamzah Bendahara merupakan lengan dari simpang lima. Sedangkan Jalan Sultan Malikus Saleh adalah akses jalan dari Jalan Soekarno-Hatta Aceh Besar (Arteri Primer) menuju pusat kegiatan sekunder dan seterusnya menuju pusat Kota Banda Aceh.

\section{$\underline{\text { Evaluasi Struktur Jaringan Kolektor Sekunder }}$}

Jalan kolektor sekunder adalah jalan yang menghubungkan kawasan sekunder kedua dengan kawasan sekunder kedua atau menghubungkan kawasan sekunder kedua dengan kawasan sekunder ketiga. Daftar jalan Kolektor Sekunder Kota Banda Aceh dapat dilihat pada Tabel 13 sebagai berikut.

Tabel 13. Struktur Hubungan Ruas Jalan Kolektor Sekunder

\begin{tabular}{|c|l|l|}
\hline No & \multicolumn{1}{|c|}{ Nama Jalan } & \multicolumn{1}{c|}{ Hubungan } \\
\hline 1 & Jalan. Rama Setia Lampaseh Kota & Jalan Alternatif Pelabuhan Feri Ulele-Pasar Aceh \\
\hline 2 & Jalan. Hasan Saleh & Jalan Dalam Pusat Kegitan Sekunder (Neusu) \\
\hline 3 & Jalan. Muhammad Jam & Jalan Dalam Pusat Kegitan Primer (Pasar Aceh) \\
\hline 4 & Jalan. K.H. Ahmad Dahlan & Jalan Dalam Pusat Kegitan Primer (Pasar Aceh) \\
\hline 5 & Jalan. Diponegoro & Jalan Dalam Pusat Kegitan Primer (Pasar Aceh) \\
\hline 6 & Jalan. Tentara Pelajar & Jalan Dalam Pusat Kegitan Primer (Pasar Aceh) \\
\hline 7 & Jalan. Cut Mutia & Jalan Dalam Pusat Kegitan Primer (Pasar Aceh) \\
\hline 8 & Jalan. Khairil Anwar & Jalan Dalam Pusat Kegitan Primer (Penayong) \\
\hline 9 & Jalan. Ahmad Yani & Jalan Dalam Pusat Kegitan Primer (Penayong) \\
\hline 10 & Jalan. W.R. Supratman & Jalan Dalam Pusat Kegitan Primer (Penayong) \\
\hline 11 & Jalan. T. Daudsyah & Jalan Dalam Pusat Kegitan Primer (Penayong) \\
\hline 12 & Jalan. Sisingamangaraja & Jalan Dalam Pusat Kegitan Primer (Penayong) \\
\hline 13 & Jalan. Pocut Baren & F23 (Jeulingke) - F21 (Lampulo) \\
\hline
\end{tabular}

Jalan Hasan Saleh berada pada pusat kegiatan sekunder yang merupakan terusan dari Jalan Sultan Malikus Saleh. Jalan Rama Setia Lampaseh Kota merupakan jalan akses dari Pelabuhan Penyeberangan Ulee Lheue menuju Pasar Aceh. Sedangkan Jalan Muhammad Jam, Jalan Ahmad Dahlan, Jalan Diponegoro menghubungkan Jalan Jalan. Tgk. Chik Ditiro (arteri primer) yang berada didalam pusat kota lama Pasar Aceh. Jalan Tentara Pelajar dan Jalan Cut Mutia menghubungkan Pasar Aceh dengan Pasar Peunayong. Jalan Khairil Anwar, Jalan Ahmad Yani, Jalan W.R. Supratman dan Jalan T. Daudsyah berada di dalam kawasan primer Penayong. 


\section{DAFTAR PUSTAKA}

Pemerintah Kota Banda Aceh. 2018. Data Geografis Kota Banda Aceh. http://kinerja.kotabandaaceh.go.id (di akses 17 September 2018).

Kimpraswil (2004). Penentuan Klasifikasi Fungsi Jalan di Kawasan Perkotaan. Departemen Pemukiman dan Prasarana Wilayah

Kimpraswil (2004a). Pedoman Konstruksi dan Bangunan Pd T-18-2004-B - Penentuan Klasifikasi Fungsi Jalan di Kawasan Perkotaan.

SK Men PUPERA 248/15. Keputusan Menteri Pekerjaan Umum dan Perumahan Rakyat Nomor 248/KTS/M/2015. Tentang Penetapan Ruas Jalan Dalam Jaringan Jalan Primer Menurut Fungsinya Sebagai Jaringan Arteri Primer (JAP) dan Jalan Kolektor Primer $1(J K P-1)$.

SK Men PU 58/12. Keputusan Menteri Pekerjaan Umum Nomor 58/KPTS/M/2012. Tentang Kelas Jalan Berdasarkan Daya Dukung Untuk Menerima Muatan Sumbu Terberat dan Dimensi Kendaraan Bermotor di Pulau Jawa dan Pulau Sumatera.

PemKot Banda Aceh. (2009). Qanun Kota Banda Aceh No.4 Tahun 2009 tentang Rencana Tata Ruang Wilayah Kota Banda Aceh Tahun 2009-2029. Pemerintah Kota Banda Aceh.

PemKot Banda Aceh. (2009). Rencana Tata Ruang Wilayah Kota Banda Aceh (RTRW) Kota Banda Aceh 2009 - 2029. Pemerintah Kota Banda Aceh. Banda Aceh.

PP 34/06. Peraturan Pemerintah Republik Indonesia Nomor 34 Tahun 2006 tentang Jalan.

Suprayitno, H. \& Soemitro, R.A.A. (2018). "Preliminary Reflexion on Basic Principle of Infrastructure Asset Management". Jurnal Manajemen Aset Infrastruktur \& Fasilitas, Volume 2, Nomor 1, Maret 2018, Hal. : 1-9.

UU 38/04. Undang-Undang Republik Indonesia Nomor 38 Tahun 2004 tentang Jalan.

UU 22/09. Undang-Undang Republik Indonesia Nomor 22 Tahun 2009 tentang Lalu Lintas Angkutan Jalan. 
(e)ISSN 2615-1847 (p)ISSN 2615-1839

Jurnal Manajemen Aset Infrastruktur \& Fasilitas - Vol. 2, Sup. 2, Desember 2018 